\title{
Antioxidants Response of Two Tomato Varieties to Fungicides and Acetylsalicylic Acid Treatments
}

\author{
Ramona Aurelia HOROTAN ${ }^{1 *}$, Simona OANCEA ${ }^{2)}$, Al. S. APAHIDEAN ${ }^{1)}$ \\ ${ }^{1}$ Departament of Horticulture, University of Agricultural Sciences and Veterinary Medicine, \\ 400372 Calea Mănăștur 3-5, Cluj-Napoca, România \\ ${ }^{2}$ Lucian Blaga University of Sibiu, Department of Agricultural Sciences and Food Engineering, Sibiu \\ ${ }^{*}$ Corresponding author, e-mail: aurahorotan@yahoo.com
}

Bulletin UASVM Horticulture 72(1) / 2015

Print ISSN 1843-5254, Electronic ISSN 1843-5394

Doi:10.15835/buasvmcn-hort:10585

\begin{abstract}
The antioxidants (ascorbic acid and total phenolics) activity was evaluated as a comparative study regarding the influence of selected systemic fungicides, $\mathrm{CuSO}_{4}$ mixture and acetylsalicylic acid on tomato fruits. Experimental crop consisted of two tomato varieties on which three types of treatments were applied. The antioxidants analysis was performed by spectrophotometric methods both for ascorbic acid and total phenolics determination. Our results showed significant differences regarding the antioxidants level in the experimental tomato crops.
\end{abstract}

Keywords: acetylsalicylic acid, fungicides, Lycopersicon esculentum.

\section{INTRODUCTION}

It is known that by consumption of nonorganic plant food, there is a great risk of ingestion of pesticide traces that are most likely stocked in plant. Abiotic constraints are responsible for oxidative stress, which causes imbalances between pro-oxidants and antioxidants in tomato (Horotan and Oancea, 2013). The tomato antioxidant potential depends on varieties and cultivation systems. Cwalina-Ambroziak et al. (2012) found a very low content of reducing sugars and phenols (2.33 mg $\left.100 \mathrm{~g}^{-1}\right)$ in the tomato treated with fungicides comparing with those untreated (control group) (3.80 mg $100 \mathrm{gg}^{-1}$ ). The results obtained by Hallman (2012) showed a significant higher content of vitamin $\mathrm{C}$ in organic tomatoes (430.14 mg dry weight) compared to conventional tomatoes (380.84 mg dry weight).

\section{MATERIALS AND METHODS}

The two experimental tomato crops, the Sibiu local population and Buzău 50, both with undetermined growth, were treated with three types of treatment: (1) systemic fungicid Acrobat
MZ 90/600 WP (TP), (2) $\mathrm{CuSO}_{4}$ (bordeaux) mixture - sustainable treatment (TS) and (3) acetylsalicylic acid solution (TA) (5g/10 l water/100 m²). From the two tomato varieties, 6 experimental variants located in 3 replicates resulted. The antioxidants analysis was performed by spectrophotometric method using 2,6- dichlorophenolindophenol for ascorbic acid determination (ISO 6557/2 1984) and Folin-Ciocalteu for total phenolics determination, respectively (Singleton et al, 1965). Results were expressed in $\mathrm{mg} 100 \mathrm{~g} \mathrm{~g}^{-1}$ of fresh weight. The 6 tomato samples used in the laboratory were collected at the same time of the day after an Phytophthora infestans attack. Samples have been frozen for 25 days at $-18^{\circ} \mathrm{C}$ until analysis. Statistical analysis was performed using t-test for dependent valued.

\section{RESULTS}

The results obtained showed significant differences regarding the ascorbic acid level in the experimental tomato crops. Tomatoes sprinkled with TA showed very significant increase of ascorbic acid level compared with the tomatoes 
Tab.1. The content of ascorbic acid and total phenolics in fresh tomatoes.

\begin{tabular}{|c|c|c|c|c|c|c|c|c|c|c|}
\hline \multirow[b]{2}{*}{ Treatment } & \multicolumn{5}{|c|}{ Ascorbic acid (mg $100 \mathrm{~g}^{-1}$ ) } & \multicolumn{5}{|c|}{ Total Phenolics (mg GAE $100 \mathrm{~g}^{-1}$ ) } \\
\hline & $\begin{array}{l}\text { Local } \\
\text { pop. }\end{array}$ & $\begin{array}{c}\text { Buzău } \\
50\end{array}$ & Dif. & $\mathrm{p}$ & Semnif & $\begin{array}{l}\text { Local } \\
\text { pop. }\end{array}$ & $\begin{array}{c}\text { Buzău } \\
50\end{array}$ & Dif. & $\mathrm{p}$ & Semnif \\
\hline $\mathrm{TP}$ & 50.074 & 28.195 & - & - & - & 37.071 & 38.749 & - & - & - \\
\hline $\mathrm{TA}$ & 88.804 & 63.960 & -37.250 & 0.0252 & $* *$ & 28.896 & 27.614 & 9.655 & 0.0971 & ns \\
\hline TS & 45.842 & 50.028 & -8.805 & 0.6217 & ns & 41.266 & 31.865 & 1.345 & 0.8485 & ns \\
\hline
\end{tabular}

The differences are significant at $\mathrm{p}<.05000$

sprinkled with systemic fungicid (considered as control group). For the variety Buzau 50, the amounts of ascorbic acid in tomatoes sprinkled with TA and TS, was over $120 \%$ to those sprinkled with TA and over $70 \%$ to those sprinkled with TS, compared to the control group (TP) (tab.1). Stephane George et al (2011) found an ascorbic acid content of $15.8 \mathrm{mg} 100 \mathrm{~g}^{-1}$ of fresh tomato. Violeta Nour et al (2013) has obtained ascorbic acid values betwen 91.9 - $329.7 \mathrm{mg} \mathrm{kg}^{-1}$ and Atila Gulec et al (2013) $6.43 \mathrm{mg} \mathrm{g}^{-1}$ fresh weight.

The level of total phenolics in tomatoes sprinkled with TA decreased by approximatively $15 \%$, both in the local Sibiu population and the variety Buzau 50. The sustainable treatment for tomato local population determined an increase of total phenolics level, while tomatoes of the variety Buzau 50 showed a slight decrease, compared to TP (tab.1). As demonstrated by Peter S. Boches et al (2009), total phenolics in tomato are between 40.05 - 81.85 mg GAE $100 \mathrm{~g}^{-1}$. Also, Violeta Nour et al (2013) reported that total phenolics in fresh tomato is between $312.2-557.8 \mathrm{mg} \mathrm{kg}^{-1}$ and Atila Gulec et al (2013) obtained 51.53 mg GAE $100 \mathrm{~g}^{-1}$.

\section{CONCLUSIONS}

Fungicides Acrobat MZ 90/600 WP inhibited the ascorbic acid production in tomato crop of Buzău 50 cultivar. Acetylsalicylic acid stimulated the ascorbic acid production in tomato crop of Sibiu local population. It was found that the applied treatments on tomatoes have not a significant effect on the amount of total phenolics. The sustainable treatment $\left(\mathrm{CuSO}_{4}\right.$ mixture $)$ resulted in an increased level of total phenolics only in the local population of tomato.

Acknowledgements: This paper was published under the frame of European Social Fund, Human Resources Development Operational Programme 2007-2013, project no. POSDRU/159/1.5/S/ 132765 .

\section{REFERENCES}

1. Güleç A, Nergiz-Unal R, Akyol A, Acar J (2013). Phenolic content and ascorbic acid are major contributors to antioxidant capacity of fruits and vegetables commonly consumed in Turkey, Journal of Food, Agriculture \& Environment, vol.11 (3\&4), 463-468.

2. Boches P (2009). Breeding Tomato for increased fruit phenolics, https://books.google.ro.

3. Horotan A, Oancea S (2013). Effects of fungicide and acetylsalicylic acid treatments on the physiological and enzymatic activity in tomato (Lycopersicon esculentum Mill.), Acta Universitatis Cibiniensis Series E: Food Technology, vol. XVII (no. 1), 13-26.

4. Nour V, Trandafir I, Mira I (2013). Antioxidant compounds, mineral contentand antioxidant activity of several tomato cultivars grown in Southwestern Romania, Notulae Botanicae Horti Agrobotanici Cluj Napoca, vol. 41(1), 126135.

5. Singleton VL, Rossi JA Jr. (1965). Colorymetry of total phenolics with phosphomolybdic

6. -phosphotungstic acid reagents, Amer. J. Enol. Viticult., Vol.16, 144-158;

7. George S, Tourniaire F, Gautier H, Goupy P, Rock E, Caris Veyrat C (2011). Changes in the contents of carotenoids, phenolic compounds and vitamin $\mathrm{C}$ during technical processing and lyophilisation of red and yellow tomatoes, Food Chemistry, 124, 1603-1611. 